\title{
Post-vaccination Immunity to Pneumococcal, Haemophilus Influenzae Type B Infection and Influenza in Patients with Chronic Obstructive Pulmonary Disease (COPD)
}

Mikhael Petrovich Kostinov ${ }^{1}$, Andrey Dmitrievich Protasov², Alexander Victorovich Zhestkov², Dmitry Vladimirovich Pakhomov ${ }^{1 *}$, Anna Vladimirovna Chebykina $^{3}$ and Tatiana Alexandrovna Kostinova ${ }^{1}$

${ }^{1}$ Mechnikov Research Institute of Vaccines and Sera RAMS, Moscow, Russia

${ }^{2}$ Samara State Medical University, Russia

${ }^{3}$ Research Institute of Pulmonology, Moscow, Russia

*Corresponding author: Dmitry Vladimirovich Pakhomov, senior researcher of Laboratory of vaccination and immunotherapy of allergic diseases Institute of sera and vaccines Russian Academy Of Medical Science, Moskow, Russia, Tel: +7-916-188-74-53, E-mail: dm_pachomov@mail.ru

Rec date: 15 Jan 2014; Acc date: 25 Feb 2014; Pub date: 28 Feb 2014

Copyright: (c) 2014 Pakhomov DV, et al. This is an open-access article distributed under the terms of the Creative Commons Attribution License, which permits unrestricted use, distribution, and reproduction in any medium, provided the original author and source are credited.

\begin{abstract}
Background: The goal of the present work was to study the dynamics of antibodies production to S. pneumoniae, $H$. influenzae type $b$, influenza virus strains $A / H 1 N 1, A / H 3 N 2$ and $B$ after combined vaccination of patients with chronic obstructive pulmonary disease (COPD) considering the severity of the disease.

Methods: To evaluate the dynamics of vaccination process (before vaccination and 3, 6 and 12 months later) 128 patients suffering from COPD, aged 45-80 years and with different severity of disease were examined. Group 1 $(n=48)$, which was concomitantly vaccinated by Pneumo 23, Hiberix and Grippol Plus beyond the period of exacerbation in course of the standard therapy of COPD. Group $2(n=80)$ nonvaccinated patients with COPD.

Results: Combined vaccination against pneumococcal, $\mathrm{H}$. influenzae type $\mathrm{b}$ and influenza is accompanied by production of antibodies to these infections, which persist during one year (observation period), regardless of disease severity. In patients with stage 4 COPD the level of antibodies to influenza virus in post-vaccination period was lower than in patients with stages 1,2 and 3. Probably, these patients should be vaccinated against influenza twice. Despite the fact that patients with COPD had lower levels of post-vaccination antibodies than control, they demonstrated apparent clinical effect throughout 12 months, which was recorded as reduction of both exacerbation number in 3.7 times and the need in antibacterial medications in 4.3 times.
\end{abstract}

Conclusion: Combined vaccination against bacterial and viral infections contributes to the achievement of antibody levels leading to development of significant clinical effect in patients with COPD.

Keywords: COPD; Vaccines Pneumo 23; Hiberix; Grippol Plus concomitant vaccination; Post-vaccination antibodies to pneumococcal; Haemophilus influenzae type $b$ infections and influenza

\section{Introduction}

The need to protect patients suffering from COPD against infectious diseases is proved by numerous studies and confirmed by practical health care. Up to $75-80 \%$ of COPD exacerbations have an infectious etiology [1]. Furthermore, according to GOLD data (2009), in one third of all cases it is impossible to establish a cause of development of severe COPD exacerbations [2]. According to the data of local authors the frequency of detection of Streptococcus pneumoniae in inflammatory respiratory diseases prevails over the other pathogens [3]. Haemophilus infection is less common, but its persistence in patients with COPD causes a progressive worsening of lung function and reduces the interval of remission [4]. The influenza virus is not a primary risk factor inducing COPD exacerbations in patients, but it contributes to the development of bacterial superinfection, especially S. pneumoniae, H. influenzae and others, which is the cause of death [5].

There is a great role of inflammatory mediators IL- $1 \beta$, IL-6, IL-8, TNF- $\alpha$, fibronectin, etc., which are biomarkers of inflammatory response of the respiratory tract in patients with COPD. IL-2 and IL-10 levels in COPD patients were decreased, against IL-6 level was increased. In normal antigen load in the respiratory mucosa is not unfolding major events related to the effector phase of the immune response. Celebrating a clear predominance of Th2-lymphocytes, which indicates the formation of humoral immune response necessary for adequate antibody [6-10]. COPD has Th1-dominated immune response with increased production of $\gamma$-IFN. With long-term progressive course may oppression humoral immune response, in particular the decrease in the production of one or more classes of immunoglobulins in patients with COPD. Therefore, patients with COPD are immunocompromised and in need of protection against respiratory infections. It is interesting and important whether there was in patients with COPD adequate and sufficient immune response to the complex vaccination against respiratory infections $[11,12]$. 
Citation: Kostinov MP, Protasov AD, Zhestkov AV, Pakhomov DV, Chebykina AV, et al. (2014) Post-vaccination Immunity to Pneumococcal, Haemophilus Influenzae Type B Infection and Influenza in Patients with Chronic Obstructive Pulmonary Disease (COPD). J Vaccines Vaccin 5: 221. doi:10.4172/2157-7560.1000221

Page 2 of 5

In this regard, vaccine-based prevention of pneumococcal and influenza infections is included into the complex treatment of COPD in different countries, and implemented by the European and Russian Respiratory Societies, British, American, and Canadian Thoracic Society and others.

However, the vaccination of COPD patients against $\mathrm{H}$. influenzae type $\mathrm{b}$ infection is not compulsory for any country in the world. There is also no evaluation of the efficacy of combined vaccination against three infections considering the severity of the disease.

The purpose of the study was to investigate the dynamics of production of antibodies to $S$. pneumoniae, $H$. influenzae type $b$, and influenza virus strains $\mathrm{A} / \mathrm{H} 1 \mathrm{~N} 1, \mathrm{~A} / \mathrm{H} 3 \mathrm{~N} 2$ and $\mathrm{B}$ after combined vaccination of patients with chronic obstructive pulmonary disease (COPD) considering the severity of the disease.

\section{Methods}

128 subjects suffering from COPD aged 45-80 years were enrolled into the study according to the inclusion/exclusion criteria. All patients gave informed consent on compliance with protocol requirements approved by the Committee on Bioethics. Among them 48 subjects in group 1 have been vaccinated in course of underlying disease treatment and 80 subjects in group 2 have received basic therapy only. The disease was diagnosed according to GOLD (2009) and the National Clinical Guidelines (PPO, 2009).

Vaccination was done once per saltum using commercial preparations at dose of $0.5 \mathrm{ml} \mathrm{i} / \mathrm{m}$ in different body areas. Vaccines: Pneumo 23 is a polyvalent pneumococcal polysaccharide (Sanofi
Pasteur SA, France) vaccine, Hiberix is a conjugated vaccine against Hib type b infection (GlaxoSmithKline Biologicals s.a., Belgium), Grippol Plus is a trivalent subunit vaccine against influenza (FK LLC, Petrovax, Russia).

The levels of IgG antibodies to the mixture of polysaccharide of Pneumo 23 vaccine and to the capsular polysaccharide of $\mathrm{H}$. influenzae type $b$ infection was determined by solid-phase ELISA using standard procedure and in accordance with techniques developed in immunochemical laboratory of Mechnikov Research Institute of Vaccines and Sera RAMS [6,7]. IgG antibodies to influenza virus strains were determined using hemagglutinin yield reduction assay according to the attached instructions for the standard technique and with indication of serum dilution. Antibodies were estimated in three steps following the requirements for paired sera testing: before vaccine administration and 3, 6 and 12 months later.

The results were processed by methods of descriptive statistics using the Shapiro-Wilk test, criteria of parametric statistics, Student's t-test, and non-parametric Mann-Whitney test. Statistical analysis was performed using the software package StatPlus 2009 Professional 5.8.4.

\section{Results}

Patients with COPD had no adverse effects of any kind in the postvaccination period.

Three months after vaccination the comparatively higher levels of IgG antibodies to a mixture of polysaccharides comprising Pneumo-23 were observed for all stages of COPD as compared to those before vaccination (Table 1).

\begin{tabular}{|c|c|c|c|c|}
\hline \multirow[t]{2}{*}{ COPD stage } & Before vaccination & After 3 months & After 6 months & After 12 months \\
\hline & unit $/ \mathrm{ml}$ & unit $/ \mathrm{ml}$ & unit $/ \mathrm{ml}$ & unit $/ \mathrm{ml}$ \\
\hline $1(n=2)$ & $81.45 \pm 16.16$ & $158.95 \pm 11.6^{*}$ & $139.45 \pm 10.05^{*}$ & $133.45 \pm 7.65$ \\
\hline $2(n=21)$ & $73.52 \pm 5.43$ & $144.55 \pm 10.4^{\star * *}$ & $136.66 \pm 6.23^{\star \star *}$ & $136.21 \pm 6.69^{\star \star \star}$ \\
\hline $3(n=14)$ & $84.25 \pm 7.54$ & $158.29 \pm 13.9^{* \star *}$ & $142.77 \pm 10.14^{\star \star *}$ & $129.76 \pm 9.84^{\star \star *}$ \\
\hline $4(n=4)$ & $97.88 \pm 18.51$ & $166.65 \pm 43.2^{*}$ & $150.2 \pm 16.91^{* *}$ & $153.73 \pm 16.15^{\star *}$ \\
\hline Total $(n=41)$ & $79.22 \pm 4.2$ & $152.41 \pm 7.5^{* * *}$ & $140.2 \pm 4.9^{* * *}$ & $135.58 \pm 5.03^{* * *}$ \\
\hline
\end{tabular}

Table 1: Changes of post-vaccination levels of IgG antibodies to the mixture of polysaccharides comprising Pneumo 23 vaccine in patients with COPD

Note: ${ }^{\star}-\mathrm{p}<0.05 ;{ }^{*}-\mathrm{p}<0.01 ;{ }^{* *}-\mathrm{p}<0.001-$ as compared to baseline values.

Furthermore in patients with stage 1 COPD the levels of IgG antibodies increased in 1.95 times $(\mathrm{p}<0.05)$, with stage 2 in 1.97 times $(\mathrm{p}<0.001)$, with stage 3 in 1.88 times $(\mathrm{p}<0.001)$, and with stage 4 in 1.7 times $(\mathrm{p}<0.05)$.

After 3 months the level of IgG antibodies to the mixture of polysaccharides of pneumococcal vaccine increased in 1.92 times for the entire group $(\mathrm{p}<0.001)$.

Six months after vaccination the levels of IgG antibodies to a mixture of polysaccharides comprising Pneumo 23 increased for all stages of COPD as compared to baseline values. Furthermore in patients with stage 1 COPD the levels of IgG antibodies increased in 1.71 times $(\mathrm{p}<0.05)$, with stage 2 in 1.86 times $(\mathrm{p}<0.001)$, with stage 3 in 1.69 times $(\mathrm{p}<0.001)$, with stage 4 in 1.53 times $(\mathrm{p}<0.01)$.
Investigation of the IgG antibodies levels in the total sample of patients with COPD after 6 months has demonstrated their increase in 1.77 times $(\mathrm{p}<0.001)$.

Twelve months after combined vaccination the levels of IgG antibodies to a mixture of polysaccharides of Pneumo-23 were significantly higher than baseline values for all stages of COPD, excluding stage 1 . Furthermore in patients with stage 2 COPD the levels of IgG antibodies increased in 1.85 times $(\mathrm{p}<0.001)$, with stage 3 in 1.54 times $(p<0.001)$, with stage 4 in 1.57 times $(p<0.01)$. Estimation of the IgG antibodies titre within 12 months after vaccination, regardless of the COPD severity, has demonstrated its increase in 1.71 times $(\mathrm{p}<0.001)$.

Estimation of the titre of IgG antibodies to the capsular polysaccharide of $\mathrm{H}$. Influenzae type $\mathrm{b}$ within 3 months after combined vaccination has demonstrated significantly higher values for 
Citation: Kostinov MP, Protasov AD, Zhestkov AV, Pakhomov DV, Chebykina AV, et al. (2014) Post-vaccination Immunity to Pneumococcal, Haemophilus Influenzae Type B Infection and Influenza in Patients with Chronic Obstructive Pulmonary Disease (COPD). J Vaccines Vaccin 5: 221. doi:10.4172/2157-7560.1000221

Page 3 of 5

stages 2 and 3 COPD, as compared to baseline values before vaccination (Table 2). Furthermore in patients with stage 2 COPD the levels of IgG antibodies increased in 1.83 times $(\mathrm{p}<0.001)$, with stage 3

\begin{tabular}{|c|c|c|c|c|}
\hline \multirow[t]{2}{*}{ COPD stage } & Before vaccination & After 3 months & After 6 months & After 12 months \\
\hline & unit/ml & unit/ml & unit/ml & unit/ml \\
\hline $1(n=2)$ & $1.59 \pm 0.33$ & $2.72 \pm 1.19$ & $0.92 \pm 0.32$ & $0.93 \pm 0.27$ \\
\hline $2(\mathrm{n}=21)$ & $0.84 \pm 0.07$ & $1.54 \pm 0.25^{\star * *}$ & $1.37 \pm 0.16^{\star \star \star}$ & $1.29 \pm 0.12^{\star \star \star}$ \\
\hline $3(n=14)$ & $0.89 \pm 0.1$ & $1.61 \pm 0.31^{* * *}$ & $1.39 \pm 0.14^{\star \star \star}$ & $1.26 \pm 0.12^{\star \star \star}$ \\
\hline $4(n=4)$ & $0.96 \pm 0.11$ & $2.79 \pm 1.2$ & $2.54 \pm 0.59$ & $2.12 \pm 0.46$ \\
\hline Total $(n=41)$ & $0.91 \pm 0.06$ & $1.76 \pm 0.21^{\star \star \star}$ & $1.47 \pm 0.12^{\star \star \star}$ & $1.35 \pm 0.09^{* \star *}$ \\
\hline
\end{tabular}

Table 2: Changes of post-vaccination levels of IgG antibodies to capsular polysaccharide of H. influenzae type b in patients with COPD

Note: ${ }^{* * *}$ - $p<0.001-$ as compared to baseline values.

The level of IgG antibodies to the capsular polysaccharide of $\mathrm{H}$. influenzae type $b$ in 6 months after vaccination was higher for patients with stages 2 and 3 COPD, as compared to the values before vaccination. Furthermore in patients with stage 2 COPD the levels of IgG antibodies increased in 1.63 times $(\mathrm{p}<0.001)$, with stage 3 in 1.56 times $(\mathrm{p}<0.001)$. Estimation of the titre of IgG antibodies within 6 months after vaccination, regardless of the COPD severity, has demonstrated its increase in 1.62 times $(p<0,001)$.

Twelve months after combined vaccination the levels of IgG antibodies to the capsular polysaccharide of $\mathrm{H}$. influenzae type $\mathrm{b}$ were

\begin{tabular}{|c|c|c|c|c|c|c|c|c|c|c|c|c|}
\hline \multirow[t]{2}{*}{ COPD stage } & \multicolumn{3}{|c|}{ Before vaccination } & \multicolumn{3}{|c|}{ After 3 months } & \multicolumn{3}{|c|}{ After 6 months } & \multicolumn{3}{|c|}{ After 12 months } \\
\hline & $\mathrm{H} 1 \mathrm{~N} 1$ & $\mathrm{H} 3 \mathrm{~N} 2$ & B & $\mathrm{H} 1 \mathrm{~N} 1$ & $\mathrm{H} 3 \mathrm{~N} 2$ & B & $\mathrm{H} 1 \mathrm{~N} 1$ & $\mathrm{H} 3 \mathrm{~N} 2$ & B & $\mathrm{H} 1 \mathrm{~N} 1$ & $\mathrm{H} 3 \mathrm{~N} 2$ & B \\
\hline $1(\mathrm{n}=2)$ & $55.0 \pm 0$ & $77.5 \pm 2.5$ & $\begin{array}{ll}222.5 & \pm \\
17.5 & \end{array}$ & $\begin{array}{ll}442.5 & \pm \\
37.5 & \end{array}$ & $\begin{array}{ll}2200 \\
120.0\end{array}$ & $\begin{array}{l}1180 \\
140.0\end{array} \quad \pm$ & $\begin{array}{ll}442.5 & \pm \\
37.5 & \end{array}$ & $\begin{array}{l}2200 \\
120.0\end{array}$ & 1160 & $\begin{array}{l}222.5 \quad \pm \\
17.5\end{array}$ & $\begin{array}{l}2200 \\
120.0\end{array}$ & $\begin{array}{l}660.0 \quad \pm \\
20.0\end{array}$ \\
\hline $2(n=21)$ & $\begin{array}{l}444.52 \quad \pm \\
15.71\end{array}$ & $\begin{array}{l}1106.2 \quad \pm \\
39.93\end{array}$ & $\begin{array}{l}445.0 \\
15.89\end{array}$ & $\begin{array}{l}993.3 \\
32.67\end{array}$ & $\begin{array}{l}882.9 \\
24.81\end{array}$ & $\begin{array}{l}1100 \\
16.47^{* *}\end{array}$ & $\begin{array}{ll}881.4 & \pm \\
31.95 & \end{array}$ & $\begin{array}{l}1132 \\
33.58\end{array}$ & $\begin{array}{ll}556.4 & \pm \\
11.16 & \end{array}$ & $\begin{array}{l}994.5 \quad \pm \\
33.4\end{array}$ & $\begin{array}{ll}1149 & \pm \\
34.31 & \end{array}$ & $\begin{array}{l}771.2 \\
16.32^{*}\end{array} \pm$ \\
\hline $3(n=14)$ & $\begin{array}{l}773.93 \\
43.87\end{array}$ & $\begin{array}{l}1141.8 \quad \pm \\
58.6\end{array}$ & $\begin{array}{ll}774.6 & \pm \\
24.56 & \end{array}$ & $\begin{array}{ll}557.8 & \pm \\
14.7 & \end{array}$ & $\begin{array}{l}1125 \\
39.27\end{array}$ & $\begin{array}{ll}777.8 & \pm \\
17.14 & \end{array}$ & $\begin{array}{ll}1139 & \pm \\
88.86 & \end{array}$ & $\begin{array}{ll}1104 & \pm \\
27.45 & \end{array}$ & $\begin{array}{ll}887.9 & \pm \\
28.24 & \end{array}$ & $\begin{array}{l}1149 \quad \pm \\
88.34\end{array}$ & $\begin{array}{ll}1145 & \pm \\
46.73\end{array}$ & $\begin{array}{l}779.6 \quad \pm \\
21.35\end{array}$ \\
\hline $4(n=4)$ & $\begin{array}{l}330.0 \\
16.83\end{array}$ & $\begin{array}{ll}887.5 & \pm \\
41.91 & \end{array}$ & $\begin{array}{ll}1102 & \pm \\
72.84 & \end{array}$ & $\begin{array}{l}550.0 \\
30.0\end{array}$ & $\begin{array}{l}550.0 \\
30.0\end{array}$ & $\begin{array}{l}1120 \quad \pm \\
40.0\end{array}$ & $\begin{array}{l}337.5 \\
15.48\end{array}$ & $\begin{array}{l}555.0 \quad \pm \\
15.0\end{array}$ & $\begin{array}{l}1133 \quad \pm \\
70.4\end{array}$ & $\begin{array}{l}225.0 \quad \pm \\
5.0\end{array}$ & $\begin{array}{l}440.0 \\
14.14\end{array}$ & $\begin{array}{l}1135 \\
68.98\end{array}$ \\
\hline Total $(n=41)$ & $\begin{array}{l}551.22 \quad \pm \\
16.96\end{array}$ & $\begin{array}{l}1111.7 \quad \pm \\
28.73\end{array}$ & $\begin{array}{ll}559.6 & \pm \\
13.48 & \end{array}$ & $\begin{array}{l}773.0 \\
16.88^{*}\end{array} \quad \pm$ & $\begin{array}{l}1105 \\
20.68\end{array}$ & $\begin{array}{l}1100 \pm \\
13.99^{* \star *}\end{array}$ & $\begin{array}{l}994.9 \pm \\
34.23\end{array}$ & $\begin{array}{l}1118 \\
20.34\end{array}$ & $\begin{array}{l}779.6 \\
13.37\end{array} \quad \pm$ & $\begin{array}{l}1103 \\
34.55^{\star}\end{array} \pm$ & $\begin{array}{l}1140 \\
24.35^{\star}\end{array}$ & $\begin{array}{l}779.8 \\
12.77^{*}\end{array} \quad \pm$ \\
\hline
\end{tabular}

Table 3: Changes of post-vaccination levels of IgG antibodies to influenza virus strains A/H1N1, A/H3N2, B in patients with COPD

Note: ${ }^{*}-\mathrm{p}<0.05 ;{ }^{*}-\mathrm{p}<0.01 ;{ }^{* *}-\mathrm{p}<0.001-$ as compared to baseline values

Within three months of post-vaccination period only the level of IgG antibodies to the influenza virus strain B (Brisbane) increased in 2.23 times $(p<0.01)$ over baseline value for patients with stage 2 COPD. The analysis of changes of IgG antibodies titre in patients, regardless of the severity of COPD, demonstrated an increase in titres to influenza virus strains $\mathrm{A} / \mathrm{H} 1 \mathrm{~N} 1$ in 1.43 times $(\mathrm{p}<0.05)$, and to strain $\mathrm{B}$ (Brisbane) in 1.68 times $(\mathrm{p}<0.001)$.

Within 6 months after combined vaccination no increase in titre of antibodies to tested influenza virus strains was detected in patients with COPD. higher than baseline values for patients with stage 2 and 3 COPD. Furthermore in patients with stage 2 COPD the levels of IgG antibodies increased in 1.54 times $(p<0.001)$, with stage 3 in 1.42 times $(p<0.001)$. Estimation of the titre of IgG antibodies within 12 months after vaccination, regardless of the COPD severity, has demonstrated its increase in 1.48 times $(\mathrm{p}<0.001)$.

Evaluation of the immune response to influenza virus strains $\mathrm{A} /$ H1N1, A/H3N2, B (Brisbane) in patients with COPD under concomitant vaccination is presented in Table 3 .
Within 12 months after combined vaccination the higher levels of IgG antibodies to influenza virus strain B (Brisbane) over baseline values were only observed in patients with stage $2 \mathrm{COPD}$, an increase comprised 1.58 times $(\mathrm{p}<0.05)$. Estimation of the titre of $\operatorname{IgG}$ antibodies to the strain $\mathrm{A} / \mathrm{H} 1 \mathrm{~N} 1$ within 12 months after vaccination, regardless of the severity of $\mathrm{COPD}$, has demonstrated its increase in 2.0 times $(\mathrm{p}<0.05)$, to strain $\mathrm{A} / \mathrm{H} 3 \mathrm{~N} 2$ in 1.25 times $(\mathrm{p}<0.05)$, and to strain B (Brisbane) in 1.34 times $(\mathrm{p}<0.05)$.

\section{Discussion}

The ultimate goal of the vaccination is to provide a protective effect against a specific infection, while combined vaccination has to protect against greater number of diseases. That is what the last investigations 
Citation: Kostinov MP, Protasov AD, Zhestkov AV, Pakhomov DV, Chebykina AV, et al. (2014) Post-vaccination Immunity to Pneumococcal, Haemophilus Influenzae Type B Infection and Influenza in Patients with Chronic Obstructive Pulmonary Disease (COPD). J Vaccines Vaccin 5: 221. doi:10.4172/2157-7560.1000221

Page 4 of 5

on design of combination vaccines for adults, non-inferior to monovaccine on their clinical and immunological impact, are directed to. Undoubtedly, the combination vaccines are superior to monovaccine owing to their pharmacological and economical parameters. Most importantly, they are more promising for the implementation of immunization programs in general, and also convenient for patients.

At the present stage there are no combined products for the prevention of bacterial and viral infections in adults, particularly pneumococcal, $H$. influenzae type $b$ infections and influenza. Probably, this will be implemented when designing new technology for creation of a universal influenza vaccine. In this regard, it is necessary to assess the immune response in concomitant administration of several vaccines.

We didn't found in literature any data about combined use of influenza, $\mathrm{H}$. influenzae type $\mathrm{b}$ and $\mathrm{S}$. pneumoniae vaccines in healthy people. Despite that we didn't have data to compare the lewels of the COPD patients with healthy people.

The COPD patients are immunocompromised: they had pathological levels of IL-2, IL-6, IL-10, $\gamma$-IFN lewels, immunoglobulin protection is decreased. After the once vaccination against new influenza strains COPD patients didn't achieved seroconversion and seroprotection [12]. So we decided to use two-dose schedule of influenza vaccination, despite the fact that this is not routine practice.

The obtained results indicate that concomitant vaccination of patients with COPD is accompanied by production of antibodies to a mixture of polysaccharide of Pneumo 23 vaccine as early as in the first months in the values exceeding the baseline in 1.7 times, and remaining stable at least for one year. Despite alterations in immune status all vaccinated patients with different severity of COPD had the same increase in the titres of antibodies to a mixture of $\mathrm{S}$. pneumoniae polysaccharides over the baseline. The levels of antibodies in patients with COPD vaccinated by monovaccine Pneumo 23 correspond to those in patients vaccinated by combination of Pneumo 23 with other vaccines.

The question whether these levels of antibodies to S. pneumoniae might be protective is still unresolved, as for adults there are no reference meanings. We can take into account the values obtained in the study in children, for whom an increase of antibodies in two or more times within one year after vaccination is a relatively robust level of protection.

Considering the specific features of the immune system in adult patients with COPD, it is safe to assume that an increase of antibodies level in more than 1.5 times has the same efficacy in protecting against S. pneumoniae. Moreover, the number of exacerbations in vaccinated patients dropped within one year in 3.7 times [8].

Synthesis of IgG antibodies to the capsular polysaccharide of $\mathrm{H}$. influenzae type $b$ after the combined vaccination of patients with COPD were recorded in both early and late periods of the study, regardless of the disease severity. Despite No significant increase of antibodies in patients with stage 1 and 4 COPD was observed due to the limited number of COPD patients. Separate evaluation of dynamics of production of IgG antibody to $\mathrm{H}$. influenzae type $b$ revealed an increase in antibody levels in patients with very severe COPD.

Direct comparison of results obtained for mono- and combined vaccination against Haemophilus influenzae type $b$ infection is also impossible due to the lack of such studies. Moreover, the specification of immunity against Haemophilus influenzae type $b$ infection of vaccinated adults is still not exactly defined due to lack of such researches. It might be assumed only that given antibody values are relatively protective, taking into consideration the values that are definitely protective $(0.15 \mathrm{mg} / \mathrm{ml})$ for children. The study has shown that all patients, including those with very severe COPD, had baseline levels of IgG antibodies to Haemophilus influenzae type b infection at least 5 times higher than conventionally accepted for children.

The efficacy of vaccination against influenza was assessed by only one of three criteria, namely by multiplicity of antibodies increase against hemagglutinin, which is the main protective antigen [9]. According to the generally accepted criteria, the multiplicity of antibodies increase should be more than 2.5 for patients aged 18 to 60 years and more than 2 times for patients over 60 years. Since the study involved patients aged 18 to 80 years, the multiplicity of antibody titers increase can be roughly estimated to be within 2.25 times. In the entire group of vaccinated patients with COPD regardless of severity it was reported that antibodies to the influenza virus strain $\mathrm{A} / \mathrm{H} 1 \mathrm{~N} 1$ have significantly $(\mathrm{p}<0.05)$ increased within 3 months and remained at a high level in 12 months. An increase of the level of antibodies to influenza virus strain $\mathrm{A} / \mathrm{H} 1 \mathrm{~N} 1$ after 6-3-12 months comprised 1.4-1.9-2.0 times, respectively, and did not reach the conventionally accepted protective level (2.25).

Only after 12 months of post-vaccination period the level of antibodies to the influenza virus strain $\mathrm{A} / \mathrm{H} 3 \mathrm{~N} 2$ became significantly higher $(p<0.05)$ than basal, and the increase of antibody levels in 3-6-12 months was 0.9-1.1-1.3 times, respectively.

Within 3 and 12 months after vaccination antibodies to influenza virus strain $B$ (Brisbane) became significantly observable as compared to baseline values, with $\mathrm{p}<0.001$ and $\mathrm{p}<0.05$, respectively. An increase in the antibody levels in the assessed period comprised 1.7-1.3-1.3 times. Consequently, there is no increase in the levels of antibodies against other two tested strains of influenza virus in patients with COPD, registered levels did not reach an conventionally protective level of 2.25 times.

Despite the small size of the group it was of interest to investigate the production of antibodies to all strains of influenza virus in patients with stage 4 COPD during post-vaccination period. Within the defined period of 3-6-12 months there was no marked increase in the levels of antibodies to strains $\mathrm{A} / \mathrm{H} 1 \mathrm{~N} 1, \mathrm{~A} / \mathrm{H} 3 \mathrm{~N} 2$ and $\mathrm{B}$ (Brisbane), although the latter tended to stimulate antibodies production. In patients with moderate (2) and severe (3) stages of COPD within postvaccination period the levels of antibodies were significantly increased after 3 months $(p<0.01)$ and 12 months $(p<0.05)$ only to the strain $B$ (Brisbane), while antibody levels to other strains of influenza virus revealed only a tendency to increase during all terms of observation.

Within 3-6-12 months after vaccination the analysis of the multiplicity of antibodies levels in the entire group of patients with stages 1,2, 3 COPD showed antibody titres increase to the influenza virus strain $\mathrm{A} / \mathrm{H} 1 \mathrm{~N} 1$ in 1.6-2.1-2.2 times, respectively, to strain $\mathrm{A} /$ $\mathrm{H} 3 \mathrm{~N} 2$ in 1.6-1.7-1.9 times, respectively, to the strain B (Brisbane) in 2.5-2.1-1.5 times. Therefore, in post-vaccination period in patients with mild, moderate and severe stages of COPD an increase in antibody levels was observed, provided that maximum values for the influenza virus $\mathrm{A} / \mathrm{H} 1 \mathrm{~N} 1$ and $\mathrm{A} / \mathrm{H} 3 \mathrm{~N} 2$ were detected in 12 months, whereas for the strain B (Brisbane) in 3 months, with subsequent decline in 12 months. Despite the difference between increases of 
Citation: Kostinov MP, Protasov AD, Zhestkov AV, Pakhomov DV, Chebykina AV, et al. (2014) Post-vaccination Immunity to Pneumococcal, Haemophilus Influenzae Type B Infection and Influenza in Patients with Chronic Obstructive Pulmonary Disease (COPD). J Vaccines Vaccin 5: 221. doi:10.4172/2157-7560.1000221

Page 5 of 5

antibody levels to tested strains of influenza virus which ranged from 1.5 to 2.5 times for patients with stages $1,2,3$ COPD, it is suggested that post-vaccination antibodies are able to protect these patients against influenza within 1 year (observation period). Even in patients with stage 4 in the early period ( 3 months) after vaccination the increase of antibodies to the influenza virus strain $\mathrm{A} / \mathrm{H} 1 \mathrm{~N} 1$ was observed comprising 1.7 times and 1.2 times for the strain $\mathrm{B}$ (Brisbane), moreover in subsequent periods of observation the levels of antibodies remained constant.

The feasibility of vaccination against influenza is confirmed by the analysis of the baseline values of antibodies to influenza viruses. Hence, before study onset all patients with COPD (excluding only 2 patients with stage 1) have titres of antibodies exceeding 1:40 (relatively protective). However, it is not possible to evaluate the protective efficacy of these levels, especially taking into account the changes in the immune status of these patients. Apparently, vaccination is accompanied by stimulation of immunological memory in patients who were previously suffered from influenza or were vaccinated against it.

There were no differences in the synthesis of antibodies in patients with COPD in concomitant vaccination as compared to monopreparation. In 6 and 12 months after vaccination of patients with COPD by Grippol Plus the increase in antibody titer to strains of the influenza virus $\mathrm{A} / \mathrm{H} 1 \mathrm{~N} 1, \mathrm{~A} / \mathrm{H} 3 \mathrm{~N} 2$ and $\mathrm{B}$ (Brisbane) comprised 2.5-1.8-3.1 times against 1.4-1.4-2.0 times over baseline, respectively [10].

Thus, the combined vaccination of COPD patients against pneumococcal, Haemophilus influenzae type $b$ and influenza is accompanied by the synthesis of antibodies to these infections, and achieved levels remain stable for at least 12 months, regardless of the disease severity.

The following fact attracts special attention - patients with stage 4 COPD had lower lewels of antibodies to influenza virus in postvaccination period against patients with stages 1,2 and 3. Probably, these patients should be vaccinated against influenza twice. Despite the fact that patients with COPD in post-vaccination period had slightly lower levels of antibodies against healthy subjects, they have a pronounced clinical effect for 12 months, which appears as a drop of exacerbations number in 3.7 times as well as a decrease in the need in antibacterial medications in 4.3 times. Taken together these data demonstrate the convincing protective effect of combined vaccination against bacterial infections and influenza.

\section{References}

1. Chuchalin AG (2008) Chronic obstructive pulmonary disease. Moscow, Russia: Atmosphere.

2. Saha S, Doe C, Mistry V, Siddiqui S, Parker D, et al. (2009) Granulocytemacrophage colony-stimulating factor expression in induced sputum and bronchial mucosa in asthma and COPD. Thorax 64: 671-676.

3. Vishniakova LA, Putov NV (1990) The etiology of acute pneumonia. Ter Arkh 62: 15-18.

4. Sinopalnikov A, Romanov AG (2006) An infectious exacerbation of chronic obstructive pulmonary disease. Pulmonology 1.

5. Centers for Disease Control and Prevention (CDC) (2009) Bacterial coinfections in lung tissue specimens from fatal cases of 2009 pandemic influenza A (H1N1) - United States, May-August 2009. MMWR Morb Mortal Wkly Rep 58: 1071-1074.

6. Vaneeva NP, Yastrebova NE, Kostinov MP (2008) The method for detection of postvaccinal immunity to antigens of the vaccine "Pneumo-23" Russia Federation patent? 233: 1074.

7. Yastrebova NE, Vaneeva NP, Markina OA (2008) The method of detection of antibodies to the capsular polysaccharide of Haemophilus influenza type b. Russia Federation patent? 233: 1075.

8. Protasov AD, Zhestkov AV, Lavrenteva NE, Kostinov MP, Ryzhkov AA (2011) The effect of complex vaccination against pneumococcal, Haemophilus influenzae type $b$ infections and influenza in patients with chronic obstructive pulmonary disease. $\mathrm{Zh}$ Mikrobiol Epidemiol Immunobiol 4: 80-84.

9. Luss LV, Kostinov MP (2008) The analysis of the reactions noted after influenza vaccination in children of Perm region. Consilium Medicum 9: 106-111.

10. Kostinov MP, Chuchalin AG, Chebykina (2011) A Post-vaccination immunity to influenza in the first time and re-vaccinated patients with bronchopulmonary pathology. Infectious immunology 6: 306-310.

11. Babanov CA (2008) Clinic-immunogical characteristics, risk factors and COPD prognoses in in the large industrial sector in Volga region. Abstract of thesis on competition of a scientific degree doctor of Medical science. Samara.

12. Tchebykina AV (2012) Clinic-functional status, immune response against influenza virus in vaccinated COPD and bronchial asthma patients. Abstract of thesis on competition of a scientific degree doctor of Medical science. Moscow. 